\title{
Pericentrin 変異マウスにおける神経系繊毛
}

三好 耕

岡山大学大学院医娈薬学総合研究科 神経情報学

キーワード：神経系瀻毛, pericentrin, 嗅覚, 抗うつ

\section{Neuronal cilia in pericentrin mutant mice}

Ko Miyoshi

Department of Brain Science, Okayama University Graduate School of Medicine, Dentistry and Pharmaceutical Sciences

\section{要旨}

Pericentrin 遺伝子にホモで変異を持つマウス（ホモ 変異マウス）では中枢神経系 1 次繊毛および嗅覚神経 細胞の嗅繊毛の低形成が観察された。自発運動量, 不 安関連行動および海馬歯状回顆粒細胞下層での神経新 生は, ホモ変異マウスと野生型マウスの間で有意な差 異を認めなかった。一方, ホモ変異マウスは嗅覚機能 の低下に加えて抗うつ行動を示したことから, 中枢神経 系 1 次繊毛の低形成は抗うつ効果を持つと考えられた。

\section{緒言}

哺乳類では神経細胞を含む大部分の体細胞が，細胞 あたり 1 本の不動性繊毛（1 次繊毛, primary cilia） を持つことは以前から知られていたが，1 次繊毛が進 化上の残遺物ではなく細胞のアンテナとしての意義を 持つことが最近認識されつつあり ${ }^{1)}$, 広範な組織で 1

平成 22 年 7 月受理

厂700-8558 岡山市北区鹿田町 2-5-1

電話：086-235-7410 FAX : 086-235-7412

E-mail :miyoshi@cc.okayama-u.ac.jp
次繊毛から細胞体, 核へのシグナル伝達機構が存在し, 細胞のホメオスタシスの維持に寄与している可能性が 指摘されている。近年セロトニン 6 型受容体やソマト スタチン 3 型受容体などが，脳の各部位の神経細胞 1 次繊毛上に発現していることが見出された ${ }^{2)}$. この知 見は神経細胞 1 次繊毛がこれらの受容体を介して細胞 近傍環境を感知していることを示唆し，さらにセンサ 一としての神経細胞 1 次繊毛から細胞体，核へ送られ たシグナルが惹起する反応が，神経伝達機構を修飾す る可能性を提示している.

中心体タンパクとして知られていた pericentrin は 繊毛形成への関与が最近明らかになった分子である。 我々は pericentrin のアイソフォームを同定するとと もに ${ }^{3)}$, 胎生期マウスの大脳皮質等で pericentrin タン パクが 1 次繊毛の基部に発現していることを見出し た 。更に我々は pericentrin 遺伝子第 1 エクソンの非 翻訳領域にトラップベクター配列が逆向きに導入され たために pericentrinの発現が低下する遺伝子改変マ ウスを作成した5)。これを用いて，神経系繊毛の形成 阻害が脳の組織学的構築, 不安やうつに関連した行動, ストレスや記憶・学習に関わるとされる海馬歯状回で の神経新生に及ぼす影響を明らかにすることを通し

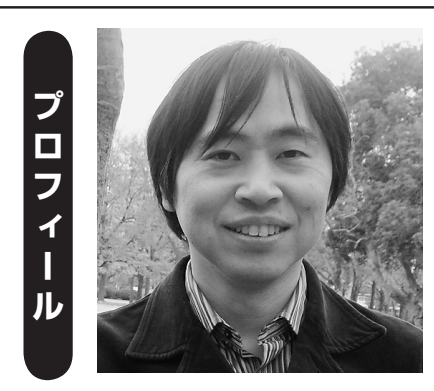

昭和43年12月 1 日生

平成 5 年 3 月 大阪大学医学部卒業

平成14年 3 月 大阪大学大学院医学系研究科博士課程修了

平成14年 4 月 大阪大学医学部附属病院 医員

平成15年 4 月 岡山大学大学院医歯学総合研究科神経情報学分野 助手

平成17年 4 月 岡山大学大学院医歯薬学総合研究科神経情報学分野 助手

平成19年 4 月 助手は助教となった

現在に至る 
て, 神経系繊毛の生体における機能を解析することを 目的とした。

\section{研究成果}

\section{Pericentrin 変異マウスの神経系繊毛の観察}

ソマトスタチン 3 型受容体 (SSTR3) 抗体, メラニ ン凝集ホルモン 1 型受容体 (MCHR1) 抗体, アデニ ル酸シクラーゼ 3 型（AC3）抗体を用いた免疫蛍光染 色により中枢神経系での 1 次繊毛の形成を比較検討し た。線条体（図 1, 2), 海馬歯状回顆粒細胞層（図 3 ), 嗅球顆粒細胞層（図 4 ）等で pericentrin 遺伝子

野生型
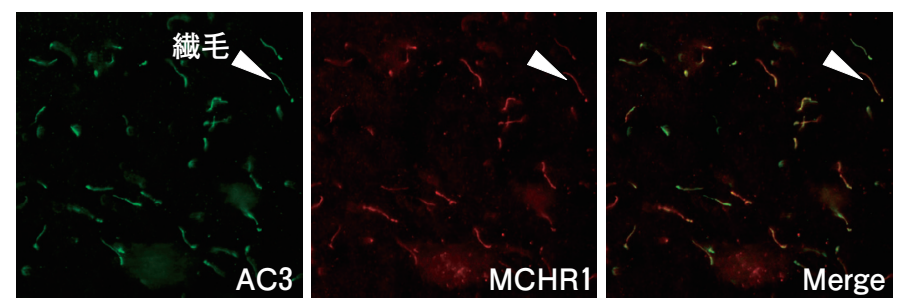

Pcnt 変異型
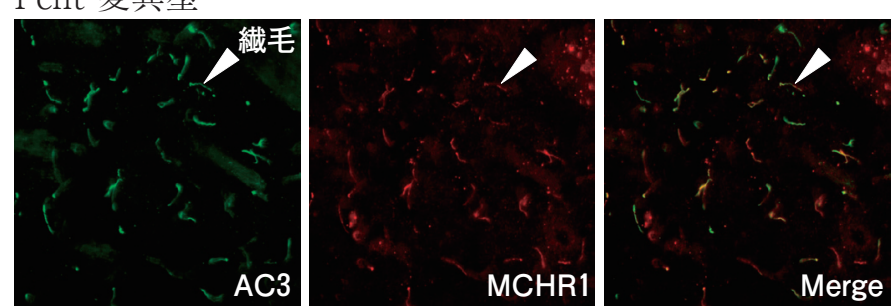

図 1 線条体の繊毛
にホモで挿入ベクター配列を持つマウス（ホモ変異マ ウス）では神経細胞 1 次繊毛の低形成を認めた。嗅粘 膜のアセチル化チューブリン抗体を用いた免疫蛍光染 色では，嗅覚神経細胞の嗅繊毛の低形成をホモ変異マ ウスで認めた（図 5 )。また Nissl 染色による観察では 大脳皮質の層構造，海馬の細胞構築，および個々の神 経細胞の極性，軸索や樹状突起の伸展およびネットワ ークの形成に関して，木モ変異マウスと野生型マウス の間で有意な差異を認めなかった。以上により, pericentrin 変異マウスは特に神経系繊毛の機能解析 に有用であると考えられた。

哺乳類の pericentrin とショウジョウバエの d-plp
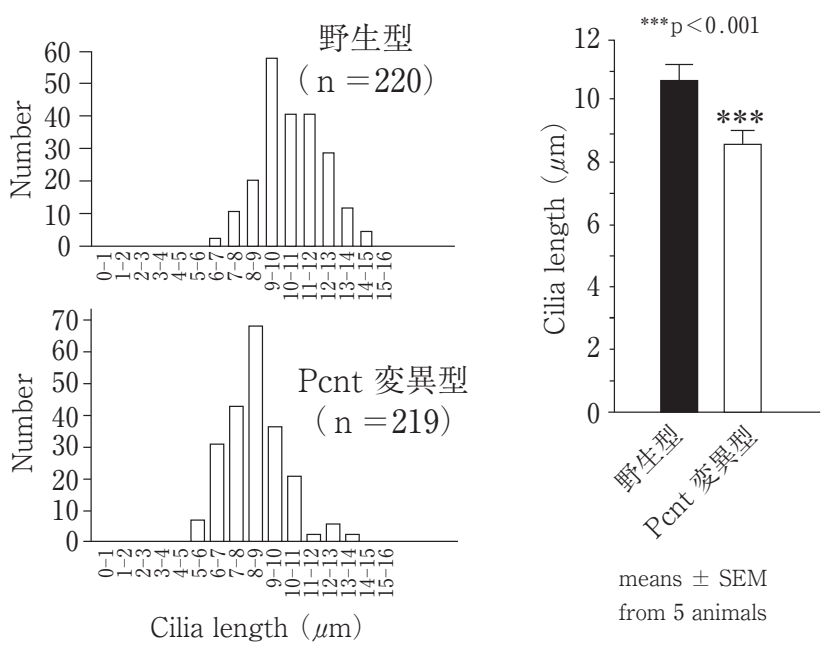

図 2 線条体における繊毛長のヒストグラムおよび平均長の比較

\section{野生型}

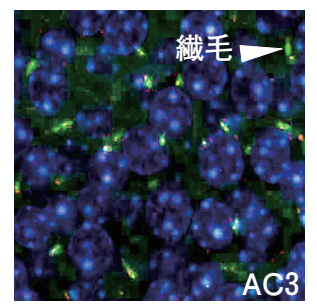

Pcnt 変異型

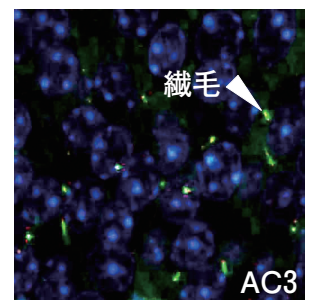

図 3 海馬歯状回の繊毛
野生型

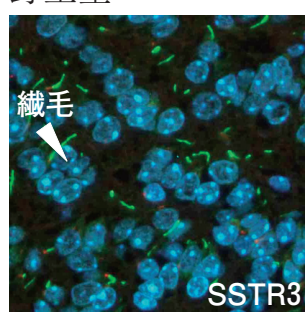

Pcnt 変異型

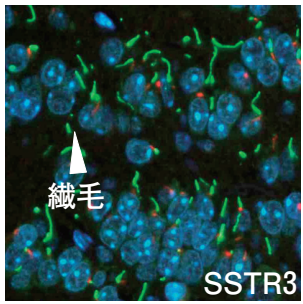

図 4 嗅球の繊毛
野生型
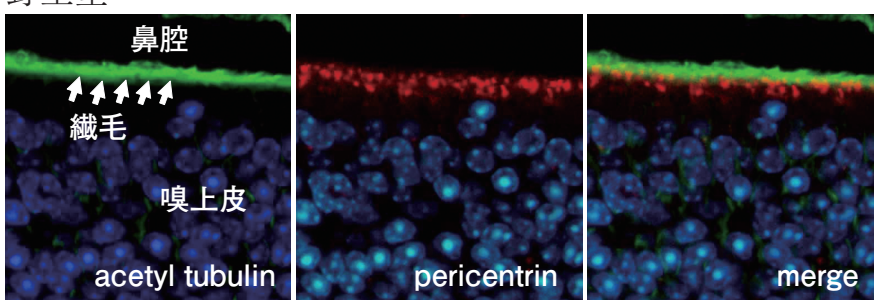

Pcnt 変異型
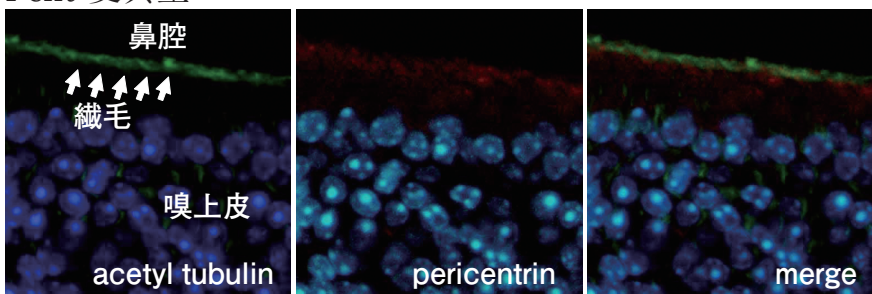

図 5 嗅覚神経細胞の繊毛 
は，それらがコードするタンパクが中心体移行に必要 なカルボキシ末端のPACTドメインを共有する coiled-coil 構造を持つことから，相同遺伝子であると 考えられてきた。初めての生体での pericentrin の機能 解析である本研究は, d-plp の変異によりショウジョウ バエの感覚神経細胞の繊毛形成が阻害されるのと同様 に, pericentrinの変異により哺乳類の神経細胞の繊毛 形成が阻害されることを示すことで，機能面から遺伝 子の相同性を確認した。すなわち中心体タンパクのう ち PACT ドメインを持つものは, 非脊椎動物から脊椎 動物まで conserve された, 神経細胞の繊毛形成に必要 な役割を担っていることを明らかにした。

\section{Pericentrin 変異マウスの行動解析 (各行動解析} では, オス, 8-10週齢のホモ変異マウスと野生型マウ スを用いた。）

\section{1 ）自発運動の測定}

セロトニンの放出を促進する para-chloroamphetamine (PCA) およびセロトニンの前駆体 5 -hydroxytryptophan ( 5 -HTP) の腹腔内投与による 自発運動の克進を activity monitor を用いて測定し た。自発運動の指標としての移動距離は, ベースライ ン值および PCA， 5 -HTPによる亢進について，ホモ 変異マウスと野生型マウスの間で有意な差異を認めな かった。よって, 中枢神経系の 1 次纎毛の低形成は自 発運動には影響を与えないことが示された。

\section{2 ）嗅覚機能の測定}

絶食後のマウスに隠したfood pellet を探索させる 嗅覚機能試験では, pelletの発見に要する時間の有意 な増大をホモ変異マウスで認めた（図 6 )。よって, 嗅 緎毛の低形成が嗅覚機能の低下を惹起したことが示さ れた。

\section{3 ）不安に関連した行動解析}

高架式十字迷路試験，明暗箱試験において，両群間 に有意な差は認めなかった。これより繊毛の低形成は 不安行動に影響を及ぼさないと考えられた。

・高架式十字迷路試験：X軸には壁を設け，Y 軸には 壁が無い十字型に交差した高架迷路での滞在時間の偏 りを 5 分間で評価する。Y軸通路の不安レベルが高い とされる。

・明暗箱試験：相互に行き来できる隣り合わせの明暗 箱での滞在時間の偏りを30分間で評価する，明るい箱 の不安レベルが高いとされる。

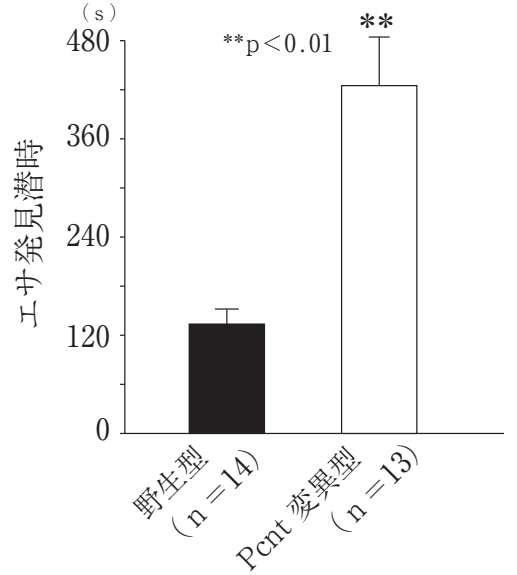

図 6 嗅覚機能試験

\section{4 ）うつに関連した行動解析}

強制水泳試験, 尾懸垂試験にて両群を比較検討した。 両試験の無動時間は抗うつ薬の投与で短縮するため, うつ状態のモデルとされている，両試験ともに，ホモ 変異マウスは野生型マウスと比較して無動時間の有意 な短縮を認めた。また試験30分前に抗うつ薬 imipramine $(30 \mathrm{mg} / \mathrm{kg})$ の腹腔内投与を行った場合，ホモ変異マウ スの無動時間はさらに短縮した（図 7，8）。これより 繊毛の低形成は抗うつ効果を持つと考えられた。

-強制水泳試験：円筒の水槽内で 6 分間泳がせ，後半 の 4 分間内の無動時間を測り，回避意欲の程度を評価 する。

・尾懸垂試験：尾を固定して 7 分間ぶら下げ，無動時 間を測り，回避意欲の程度を評価する。

MCHR1 は 1 次繊毛上に限局して発現するため, メ ラニン凝集ホルモン $(\mathrm{MCH})$ 系の伝達は繊毛に依存す ると言える。マウスにおいて MCHR1の欠損や MCHR1 選択的アンタゴニストの投与により抗うつ効 果が見られるという報告6)を踏まえるならば, MCHR1 を発現する繊毛の短縮による $\mathrm{MCH}$ 系伝達の低下がホ モ変異マウスの抗うつ行動を惹起した機序が考えられ る。今後，変異マウス脳内に $\mathrm{MCH}$ などの繊毛受容体 のリガンドを直接投与して行動学的，生化学的な変化 を観察することを通して，神経細胞の非シナプス性の 入力経路としての 1 次繊毛が情動の制御に関わるシグ ナリングの起点となっている可能性について更に検討 することが課題として挙げられる。 


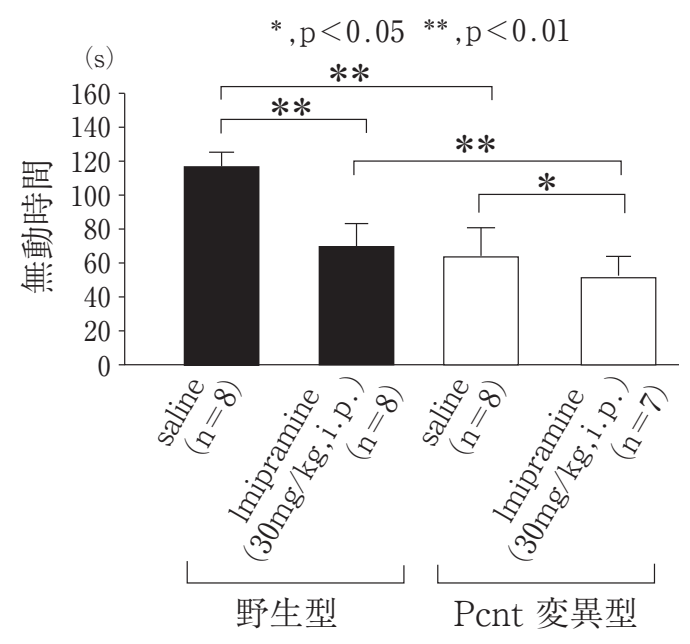

図 7 強制水泳試験

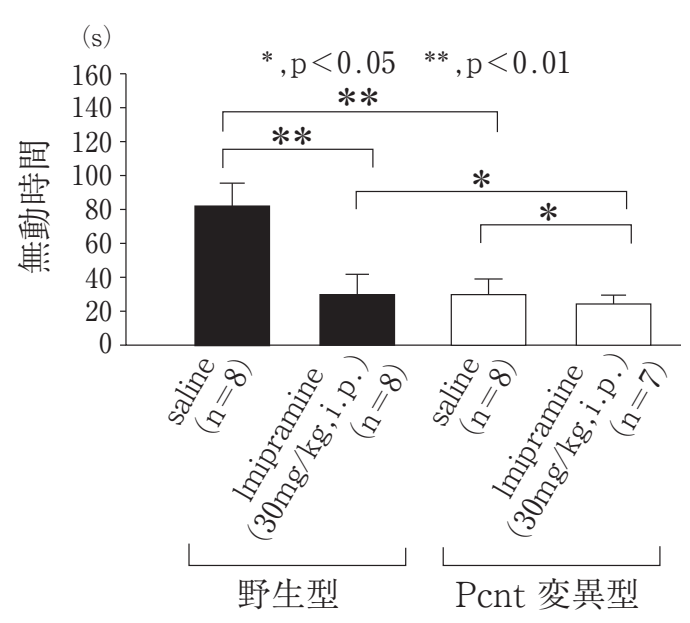

図 8 尾懸垂試験

\section{Pericentrin 変異マウスの海馬歯状回における神 経新生の計測}

成長後も神経幹細胞の増殖・分化が持続する海馬歯 状回顆粒細胞下層での神経新生を計測することによ り, 神経幹細胞の 1 次繊毛が分泌因子を感知し核への 増殖シグナルの起点になっている可能性を検討した。 Bromodeoxyuridine (BrdU) は増殖細胞の合成期 DNA に取り达まれるため, 新生細胞の標識に広く用いられ
る. ホモ変異マウスと野生型マウス (オス, 8 週齢)

に $\mathrm{BrdU}$ を腹腔内投与し $(100 \mathrm{mg} / \mathrm{kg} ； 2$ 時間おきに 4 回), 最後の投与の 48 時間後に灌流固定し, 海馬を含む 領域の冠状断連続切片を作成した。切片を 2 重免疫蛍 光染色により観察し, 歯状回顆粒細胞層の BrdU, NeuN 両陽性細胞すなわち新生神経細胞の数を計測し た。ホモ変異マウス，野生型マウス間で比較したとこ ろ, 有意な差異を認めなかった。各群についてさらに 3 群に分け, 生理食塩水, 抗うつ薬 imipramine (30mg $/ \mathrm{kg})$, fluoxetine $(20 \mathrm{mg} / \mathrm{kg})$ のいずれかを21日間連続 で腹腔内投与したうえで同様の計測を行ったが, 各群 ともに, 新生神経細胞数は抗うつ薬の投与による有意 な影響を受けなかった。以上より, 繊毛の低形成は神 経新生に影響を及ぼさないと考えられた。

\section{文献}

1) Singla V, Reiter JF: The primary cilium as the cell's antenna : signaling at a sensory organelle. Science (2006) 313, 629-633.

2) Berbari NF, Johnson AD, Lewis JS, Askwith CC, Mykytyn K : Identification of ciliary localization sequences within the third intracellular loop of $\mathrm{G}$ protein-coupled receptors. Mol Biol Cell (2008) 19, 1540-1547.

3) Miyoshi K, Asanuma M, Miyazaki I, Matsuzaki S, Tohyama M, Ogawa N : Characterization of pericentrin isoforms in vivo. Biochem Biophys Res Commun (2006) 351, $745-749$.

4) Miyoshi K, Onishi K, Asanuma M, Miyazaki I, DiazCorrales FJ, Ogawa N:Embryonic expression of pericentrin suggests universal roles in ciliogenesis. Dev Genes Evol (2006) 216, 537-542.

5 ) Miyoshi K, Kasahara K, Miyazaki I, Shimizu S, Taniguchi M, Matsuzaki S, Tohyama M, Asanuma M : Pericentrin, a centrosomal protein related to microcephalic primordial dwarfism, is required for olfactory cilia assembly in mice. FASEB J (2009) 23, 3289-3297.

6 ) Antal-Zimanyi I, Khawaja X: The role of melaninconcentrating hormone in energy homeostasis and mood disorders. J Mol Neurosci (2009) 39, 86-98. 